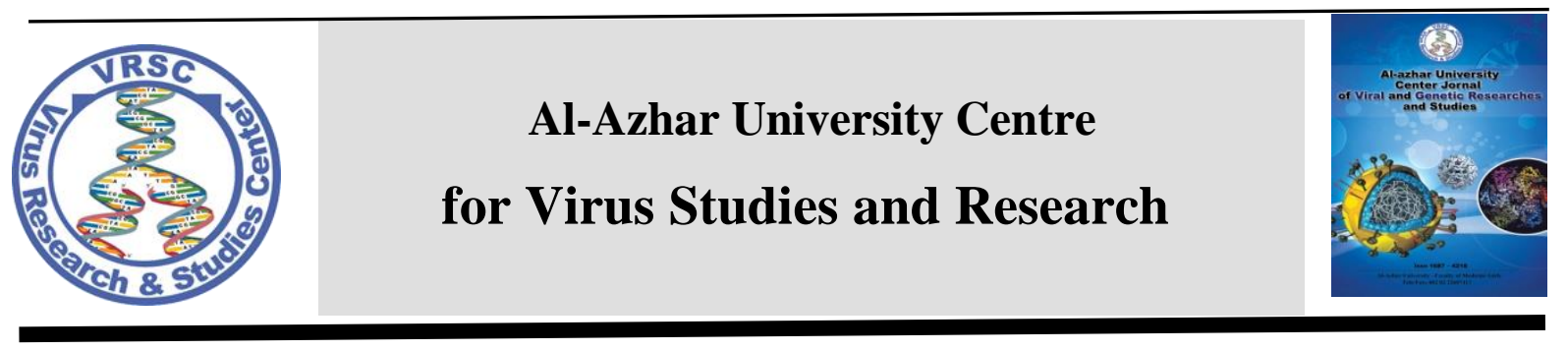

\title{
Screening and Diagnosis of Hepatitis $C$ infection in Hemodialysis Patients
}

\author{
Mervat Abd-Elminein', Mohamed Ali Abd El-Baseer², Mona Abd-gelel Mohamed ${ }^{3}$, and Omyma \\ Mohamed Elmahalowy ${ }^{4}$
}

Biochemistry Department, faculty of medicine for girls, Al-azhar university ${ }^{1}$, Microbiology and botany Department, faculty of science for boys ${ }^{2}$, Al-azhar university Biochemistry Division, Chemistry Department, faculty of sciences for girls ${ }^{3}$, Researcher in Al-Azhar university center for virus research and studies, faculty of medicine for girls ${ }^{4}$

\begin{abstract}
Study was done on Egyptian hemodialysis patient of detection of hepatitis B surface antigen (HBsAg), antibody to human immunodeficiency virus type and type 2(anti-HIVIV2) and hepatitis $\mathrm{C}$ antibody (anti-HCV). HCV antibodies are insensitive in the acute phase because of the long serological window. Direct detection of HCV depends on PCR test but this test is not suitable for routine screening. Recombinant immunoblot assays are used as supplemental tests. The results from 200 individuals 120 males $(60 \%)$ and 80 females $(40 \%)$ in the eight dialysis centers in Egypt were analyzed in this study. All patients were negative for antibodies to HIV and HBsAg. Hepatitis C antibody (anti-HCV) 100 patients were negative HCVAb $(50 \%), 70$ pateints positive HCVAb (35\%). 30 patients were in grey zone (15\%) Twenty patients from 100 negative HCVAb as control group were confirmed by HCVRNA (PCR), 7 were positive $(35 \%)$ and $13(65 \%)$ were negative. The grey zone 30 patients showed $2(6.7 \%)$ negative and $28(93.3 \%)$ positive HCVRNA. Thirty Patients from 70 positve anti-l 1CV showed one (3.3\%)negative and $29(96.7 \%)$ positive HCV-RNA.
\end{abstract}

\section{Introduction}

$\mathrm{HCV}$ infection is a major public health problem with an estimated global prevalence of $\mathrm{HC} 4 \%$. There are about 180 million chronic carriers and approximately 4 million people annually are newly infected. (Soin et al., 2015). Hepatitis C virus (HCV) is a single-stranded positive sense RNA virus with a genome of about 10.000 nucleotides containing a single large, continuous open reading frame and with an organization most closely resembling the family Flavviridae from genus hepacivirus (Lemon.,etal 2007).

Hepatitis $\mathrm{C}$ virus (HCV) infection remains frequent in patient receiving long-term dialysis both in developed and less developed countries. Recent evidence indicates that $\mathrm{HCV}$ plays a detrimental effect on survival in the dialysis population, but it remains unknown whether the elevated mortality risk because of $\mathrm{HCV}$ infection is only attributable to an increase in liver disease-related deaths. (Fabrizi, et $a l, .2012)$.

The prevalence of HCV infection is much higher in patients on chronic hemodialysis (HD) than in the general population despite the control of blood products. Hepatitis C virus is a significant cause of morbidity and mortality in patients who is treated with dialysis (Etik et al., 2015). Virological diagnosis and monitoring of $\mathrm{HCV}$ infection 
is based on two categories of laboratory tests, namely serologic assays detecting specific antibodies to HCV (anti-HCV) and assays that can detect, quantify or characterize the components of HCV viral particles such as HCV RNA. (Kesli etal., 2011).

Early stages of the infection are missed because the antibodies develop only after one and half months of infection and the tests for anti $\mathrm{HCV}$ antibody may be negative in the initial period before the seroconversion phase (Lai 2001). This window phase can be longer in hemodialysis patients as these patients are severely immunocompromised. In such situations, the HCV RNA detection by polymerase chain reaction (RT- PCR) is highly sensitive and is a reliable test in the eai ly diagnosis of HCV infection. (Reddy et al., 2005). HCV infection is usually diagnosed based on the detection of anti$\mathrm{HCV}$ antibody, while it goes undetected in the first 4-6 weeks of infection (so-called window period). Furthermore, patients positive for anti-HCV antibody include both those who are actively infected and those who have recovered from infection. (Perico et al., 2009)

Diagnostic procedures of hepatitis $\mathrm{C}$ virus infection in laboratories are principally based on the detection of antibodies (IgG) against recombinant HCV polypeptides by two main methods: Enzyme immunoassay (EIA) and Chemiluminescence immunoassay (CIA). Nonstructural and recombinant antigens have been used in the production of immunoassay reactives. Serologic and virologic markers of past or present $\mathrm{HCV}$ infection include $\mathrm{IgG}$ antibodies (anti-HCV). An assay for IgM anti- HCV is available, but it does not distinguish between acute and chronic $\mathrm{HCV}$ infection.

(Ansari and, Omrani 2006). Three different generations of $\mathrm{HCV}$ kits have been developed to date. The first generation HCV enzyme immunoassay detected only antibodies against non-structural region 4
(NS4) with recombinant antigen cl00-3. First- generation anti-HCV reactive had relatively poor specify and sensitivity. In the development of second-generation tests, additional antigens from the core region (c22-3), the NS3 region (c33c) and a part of c 100-3 from the NS4 region were used. Second-generation reactive show increased sensitivity and specify. Thirdgeneration EIA includes an additional antigen from the NS5 protein and a reconfiguration of the core and NS3 antigens. (Fiebelkorn, and Nolte 2004) and (Wu FB., et al.,2008). The newest generation of immunoassays available, that is, fourth generation of tests is those that simultaneously detect HCV capsid antigen as well as antibodies to the core, NS3, NS4, and NS5 regions of the virus (Gupta et al., 2014).

\section{Patient and Methods}

Two hundred patients (20 to 74 years) suffering from renal failure and undergoing hemodialysis were selected from different hemodialysis centers in Cairo, Egypt. Serum samples patient performed the routine hemodialysis 3 times/week three months ago were investigated in Al- Azhar University Center for Virus Research.

Blood samples were collected before dialysis and serum was obtained by centrifugation at $4^{\circ} \mathrm{C}$ for $10 \mathrm{~min}$ at 5000rpm. Serum samples were aliquot and stored at $-80^{\circ} \mathrm{c}$. From the 200 patients, only 100 patients were $\mathrm{HCV}$ positive (30 were located at the grey zone). According to the results of ELISA HCV-Ab, patients $w^{r} e$ categorized into three groups:

Group I: 20 hemodialysis patients (11 males and 9 females) negative $\mathrm{HCV}-\mathrm{Ab}$ (Control)

Group II: 30 hemodialysis patients (17males and 13 females), who were suspected for $\mathrm{HCV}$ infection, since $\mathrm{HCV}$ $\mathrm{Ab}$ test was located at the grey zone range (0.5-1.5). 
Group III: 30 hemodialysis patients (16 males and 14 females) positive $\mathrm{HCV}-\mathrm{Ab}$ $(+\mathrm{HCV}-\mathrm{Ab})$.

\section{Methods}

Serum samples were tested for HIV, and HBsAg using commercial kits (ELISA DSI-Italy). HCV was detected by both ELISA (Biokit,USA) and Reverse transcriptase-PCR using the commercial kits (Qiagen ,USA) for RNA extraction while TaqTM master mix by (Fermintas ,USA).The primer used for HCV- RNA amplifid was desiged according to ELAwady et al ,(2006) .

A-outer primers:

Primer-l(PI): is $21^{\mathrm{nt}}$ sense primer sequence. 5'AACTACTGTCTTCACGCAGAA 3' Primer-2(P2): is $22^{\text {nt }}$ anti- sense primer sequence.

5'GGTGCACGGTCTACGAGACCTC 3' B-Inner Primers:

Primer-3(P 3): is $18^{\text {nt }}$ sense primer

\begin{tabular}{|l|l|l|}
\hline $\begin{array}{l}\text { Temperature } \\
\left({ }^{\circ} \mathrm{C}\right)\end{array}$ & Time (min) & Cycles \\
\hline 50 & $30: 00$ & RT Step \\
\hline 95 & $15: 00$ & Taq Activation \\
\hline 9455 & $1: 001: 00$ & PCR (40 cycle) \\
72 & $1: 00$ & \\
& & \\
\hline 75 & $10: 00$ & Final Extension \\
\hline 4 & HOLD & \\
\hline
\end{tabular}

sequence.

5'GTGCAGCCTCCAGGACCC 3*

Primer- 4(P4): is nt anti -sense primer sequence.

5ACTCGGCTAGCAGTCTCGCG 3'

An amplicon of 171 bp length was identified in positive HCV-RNA sample on $2 \%$ agarose gel with $1 \mathrm{x}$ TAE buffer, by staining the products with ethidium bromide (EL AWady et al.,2006)
Table (I): Thermal cycling conditions were as following:

\section{Results}

Our study includes 120 males $(60 \%)$ and 80 females $(40 \%)$ undergoing hemodialysis from eight dialysis centers in Egypt. In this study demonstrated all patients were negative for antibodies to HIV and HBs Ag. We detected 100 patients HCVAb-negative $(50 \%), 70$ HCVAbpositive Patients $(35 \%)$, ,30 patients in grey zone (15\%).

Table (2): Detection of Anti-HCV by ELISA Test:

\begin{tabular}{|l|c|c|}
\hline \multirow{2}{*}{ GROUPS } & \multicolumn{2}{|c|}{ ELISA RESULTS HCV-AB } \\
\cline { 2 - 3 } & NO. PATIENTS & $\%$ \\
\hline NEGATIVE & 100 & 50 \\
\hline POSITIVE & 70 & 35 \\
\hline GREY ZONE & 30 & 15 \\
\hline
\end{tabular}

An amplicon of 171 base pair length was identified in positive HCV- RNA sample on $2 \%$ agarose gel (figure 1 ).

Figure (1): PCR product for HCV-RNA on agarose gel stained with ethidium bromide.
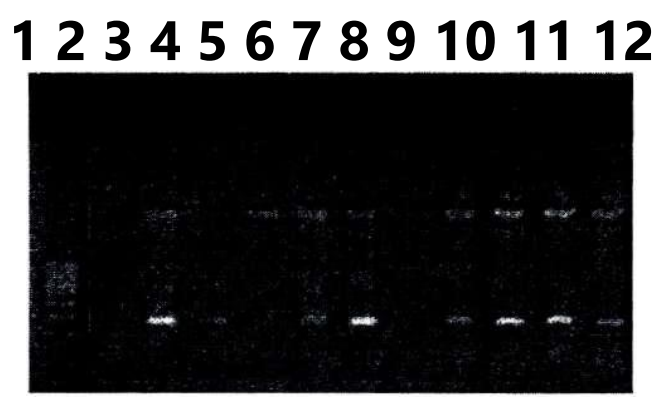

Lanell Marker, Lane 2,8: control, Lane 3-7: grey zone, Lane,9-12: antiHCV anti-HCV +ve 
Table (3): Distribution of HCV infection in hemodialysis (HD) patients within the studied groups using the two detecting tests.

\begin{tabular}{|c|c|c|c|c|c|c|}
\hline \multirow[t]{2}{*}{ Test } & \multicolumn{2}{|c|}{$\begin{array}{l}\text { Group } \\
\text { I(control) } \\
(\mathbf{n}=\mathbf{2 0})\end{array}$} & \multicolumn{2}{|c|}{$\begin{array}{l}\text { Group II(Anti HCV } \\
\text { grey zone) }(\mathbf{n}=\mathbf{3 0})\end{array}$} & \multicolumn{2}{|c|}{$\begin{array}{l}\text { Group III(Anti } \\
\text { HCV + ve) } \\
(11=30)\end{array}$} \\
\hline & $+v e$ & -ve & $+v e$ & -ve & $+\mathrm{ve}$ & -ve \\
\hline $\begin{array}{l}\text { HCV- } \\
\text { Ab } \\
\text { Numbe } \\
\text { r } \\
\%\end{array}$ & & \begin{tabular}{|l|}
20 \\
$100 \%$
\end{tabular} & $\begin{array}{l}\text { Equivoc } \\
\text { al range }\end{array}$ & - & $\begin{array}{l}30 \\
100 \%\end{array}$ & - \\
\hline \begin{tabular}{|l} 
PCR \\
Numbe \\
$\mathbf{r}$ \\
$\%$
\end{tabular} & $35 \%$ & $\begin{array}{l}13 \\
65 \%\end{array}$ & $2893.3 \%$ & $\begin{array}{l}2 \\
6.7 \%\end{array}$ & $\begin{array}{l}2996.7 \\
\%\end{array}$ & $13.3 \%$ \\
\hline
\end{tabular}

\section{Discussion}

Moini, reported that the anti-HCV tests may fail to detected $\mathrm{HCV}$ infection inl.66\% to $7.2 \%$ in patients of maintenance hemodialysis (MHD), because the immunocompromised status of these patients prevents them from having detectable anti-HCV antibodies. So necessary to detected HCV RNA by polymerase chain reaction (PCR) in antiHCV negative patients who were at high risk of $\mathrm{HCV}$ transmission (Moini etal., 2013).

Antibody tests fail to identify $\mathrm{HCV}$ infected subjects before seroconversion or during the window period, when specific antibodies have not yet been produced or are in low titres. However, the virus continues to replicate and RNA can be detected in the plasma (Carreno etal .,2012), (Hussei etal., 2010) and (Ansari etal.,2006).

Wu FB etal., 2008, reported that window period may extend up to two months in immunocompetent subjects or as long as 6 to 12 months in immune deficient patients (Wu FB eta/.,2008). Patients on hemodialysis or immunocompromised patients infected with HCV produce fewer antibodies. Direct measurement of the HCV virus in the serum of the infected individual remains the gold standard in the diagnosis of HCV infection. HCV RNA is detectable in the serum within one to two weeks after the infection. Virological diagnosis and monitoring of $\mathrm{HCV}$ infection are based on the use of serologic assays detecting specific anti- $\mathrm{HCV} \mathrm{Ab} \mathrm{(Bouvier-Alias} \mathrm{et}$ al., 2002). The anti-HCVAb test also does not distinguish the individuals who have resolved $\mathrm{HCV}$ infection from the patients with active/ongoing $\mathrm{HCV}$ infection (Kesli et al., 2011). The anti-HCV assay is simple, inexpensive and rapid as a screening test, but lacks detection sensitivity in the early window period of 45 to 68 days after infection (Florea et al., 2014).

In this study, the control group 20 patients negative in $\mathrm{HCV}-\mathrm{Ab}$ were 7 (35\%) cases positive HCV-RNA. From all number of grey zone (30 patients )2 patients were negative HCV-RNA (6.7\%)and $28 \mathrm{HCV}$ - RNA were positive (93.3\%). one patient (3.3\%) negative HCV-RNA and 29(96.7\%) HCV-RNA positive were diagnosed from the 30 $\mathrm{HCVAb}$ - Positive groups.

This was in agreement with Gioacchino,eta/,2012, Florea et al., 2014 which demonsterated that although thirdgeneration $\mathrm{HCV}$ reactive are more sensitive and specific than older generation assays, they still have a high percentage of false positive reactions, so that it is mandatory to confirm every reactivity, especially with low titers by anti- HCV RNA assay .HCV RNA is the earliest marker of infection, and a direct indicator of ongoing viral replication. It appears 1 to 2 weeks after infection before any alterations in liver enzyme levels and appearance of anti-HCV antibodies can be detected. Molecular biology techniques are the most efficient tools for the identification of HCV strains, useful both 
for diagnosis and for viral characterization studies.

The polymerase chain reaction (PCR) technique when used for $\mathrm{HCV}$ infection, allows the identification of the acute phase of the infection. This is very important, considering that anti-HCV $\mathrm{Ab}$ is not detected during this phase (Moreira et al., 2005). However, nucleic acid amplifications involve considerable technical skill, high costs and longer turnaround time and may lead to false positive results due to contamination; for these reasons, amplification methods are not suitable for wide spread use in most laboratories, especially in developing countries (Morota et al., 2009; Soliman et al., 2015). The incorporation of the viral envelope proteins could be an alternative for the development of more sensitive, new immunoenzymatic tests (Moreira et al., 2005) and (Yongjung P,eta/2010).

Therefore, the HCV Core-Ag assay is needed as a supplemental or preconfirmatory test to pre-confirm anti-HCV results (Kesli et al., 2011). In the present study, the immunoenzymatic (antiHCVAb) test fails to detect $35 \%$ of the $\mathrm{HCV}$ infected patients in control group as confirmed by the HCV RNA amplification tests, while in grey zone groups and positive group for anti-HCVAb test fails to detect 6.7 and $3.3 \%$, respectively, of uninfected patients as confirmed by the HCV RNA amplification test.

\section{Conclusion}

The HCV RNA assay is a reliable method but needs technical skill and may also result in false positivity because of contamination, and it is time intensive and more expensive in developing countries.

From this study we found that detection of HCV using anti - HCV antibody have Positive results in patients who have been recovered also may have false negative results in patients in window phase and immune compromised patients especially hemodialysis patients so we recommended in this study to use other method as confirmatory as HCVcore-Ag as it's simple ELISA technique and cheap.

\section{Reference}

1- Ansari MHK and Omrani MD. (2006): Evalutaions of diagnostic value of ELISA method (EIA) \& PCR in diagnosis of hepatitis $\mathrm{C}$ virus in hemodialysis patients. Hepatitis Monthly 6:19-23.

2- Bouvier-Alias M, Patel K, Dahari $\mathrm{H}$, Beaucourt S, Larderie P, Blatt L, Hezode C, Picchio G, Dhumeaux D, Neumann AU, McHutchison JG, Pawlotsky JM (2002): Clinical utility of total $\mathrm{HCV}$ core antigen quantification: a new indirect marker of HCV replication. Hepatology, 36:211-8.

3- Buket CA, Ay§e A, Sel?uk K, Suleyman O, Emel SC (2014): Comparison of HCV core antigen and anti$\mathrm{HCV}$ with HCV RNA results. Afr. Health Sci., 14: 816-820.

4- Carreno V, Bartolome J, Castillo I, Quiroga JA. (2012): New perspectives in occult hepatitis $\mathrm{C}$ virus infection. World J Gastroenterol; 18: 28872894

5- $\quad$ EI awady MK,Badr ELdin NG,ELGarf WT, Youssef SS,OmranMH, and EL Goueli S.(2006): Antisense oligonucleotide inhibibition of hepatitis $\mathrm{C}$ virus genotype 4 Replication in HepG2 cells,cancer cell International,6:18.

6- $\quad$ Etik DO, Ocal S, Boyacioglu AS (2015): Hepatitis C infection in hemodialysis patients: A review. World J. Hepatol 7: 885-895.

7- European Association for Study of Liver. (2014): EASL Clinical 
Practice Guidelines: (2014) management of hepatitis $\mathrm{C}$ virus infection.JHepatol; 60: $392-420$

8- Fiebelkorn KR and Nolte SH. (2004): RNA virus detection. In Persing $\mathrm{DH}$ editor in chief. Molecular MicrobiologyDiagnostic Principles and Practise. ASM Press, Washington DC, USA. pp.441-474.

9- $\quad$ Fabrizi.F, Dixit .V, Messa .P, and Martin .P,(2012) : Hepatitis C-related liver disease in dialysis patients, Contributions to Nephrology, vol. 176, pp. 42-53.

10- Florea D, Neaga E, Nicolae L, Maxim D, Popa M, Otelea D (2014): Clinical Usefulness of HCV Core Antigen Assay for the Management of Patients with Chronic Hepatitis C. J. Gastrointestin. Liver Dis., 23: 393396

11- Gioacchino Li Cavoli, Carmela Zagarrigo, Onofrio Schillaci ,2012: Hepatitis C Virus Core Antigen Test inMonitoring of Dialysis Patients, Nephrology and Dialysis, ARNAS Civico and Di Cristina Hospital, Via Francesco Cilea 43, 90144

12- Gupta E, Bajpai M, Choudhary A (2014): Hepatitis C vims: Screening, diagnosis, and interpretation of laboratory assays. Asian J. Transfus. Sci., 8: 19-25.

13- Hussein $\mathrm{MM}$ and Mooij JM. (2010): Methods used to reduce the prevalence of hepatitis $\mathrm{C}$ in a dialysis unit. Saudi J Kidney Dis Transpl; 21: 909-913.

14- Kesli R, Polat H, Terzi Y, KurtogluMG, Uyar Y (2011): Comparison of a Newly DevelopedAutomated and Quantitative Hepatitis CVirus (HCV) Core Antigen Test with the HCVRNA Assay for Clinical Usefulness inConfirming AntiHCV Results. J. Clin. Microbiol., 49:4089.
15- Lai KN.(2001): Hepatitis C infection screening in hemodialysis units. Am J Kidney Disease 2001;38:186-8.

16- Lemon SM, Walker C, Alter MJ, Yi MK. (2007) :

Hepatitis C virus In: Knipe DM, Howley PM editors-in chief. Fields Virology.5th ed. Wolters Kluwer Lippincott Williams \& Wilkins, Philadelphia, USA. pp. 12531304.

17- Moreira RC, Lemos MF, Longui CA, Granato C(2005): Hepatitis C and Hemodialysis. BJID, 9: 269-275.

18- MorotaKR, Fujinami H, Kinukawa T, Machida K, Ohno H,Saegusa H, Takeda $\mathrm{K}$ (2009): A new sensitive and automated chemiluminescent microparticle immunoassay for quantitative determination of hepatitis $\mathrm{C}$ virus core antigen. J. Virol. Methods, 157:8-14.

19- Moriishi $\mathrm{K}$ and Matsuura $\mathrm{Y}$ (2012): Exploitation of lipid components by viral and host proteins for hepatitis $\mathrm{C}$ virus infection. J. Microbiol., 3: 1-14.

20- Moini M, Ziyaeyan M, Aghaei S, Sagheb MM, Taghavi SA,Moeini M, Jamalidoust M, Hamidpour L.(2013): Hepatitis C virus(HCV) Infection Rate among Seronegative Hemodialysis Patients Screened by Two Methods; HCV Core Antigen and Polymerase Chain Reaction. Hepat Mon\13: e9147

21- Perico .N, Cattaneo.D, Bikbov.B, and Remuzzi .G, (2009): "Hepatitis C infection and chronic renal diseases," Clinical Journal of the American Society of Nephrology, vol. 4, no. 1, pp. 207-220.

22- Reddy AK, Murthy KV, Lakshmi V,(2005 ): Prevalence of HCV infection in patients on hemodialysis: Survey antibody and core antigen detection. Indian $\mathbf{J}$ Med Microbiol;23:106:10 
23- Soliman HA, Hozayen WG, Mahmoud AM, Abo-SeifMA, FayedNA(2015): Significance of the hepatitis $C$ virus core antigen testing as an alternative marker for hepatitis diagnosis in Egyptian patients. Eur. Rev. Med. Pharmacol. Sci., 19: 2240-2245.

24- Soin D, Grover P., Malhotra R., (2015): Hepatitis $\mathrm{c}$ virus infiction in dialysis patients :A retrospective study from tertiary care hospital of north india Jnt. J. Res. Dev. Pharm. L. Sci.,4(3), 15291532 Treitel M, Marbury T, Preston RA, Triantafyllou I, Feely W, O'Mara E, Kasserra C, Gupta S, Hughes EA. (2012): Single-dose pharmacokinetics of boceprevir in subjects with impaired hepatic or renal function. Clin Pharmacokinet; 51: 619-628

25- Yongjung Park, Jong-Han Lee, Beom Seok Kim, Do YoungKim, Kwang-Hyub Han, and Hyon-Suk Kim 2010 : New Automated Hepatitis C Virus (HCV) Core Antigen Assay as an Alternative to Real-Time PCR for HCV RNA Quantification.,J Clin Microbiol. Jun 2010; 48(6): 2253-2256.

26- Wu FB, Ouyan HQ, Tang XY, Zhou ZX (2008): Double-antigen sandwich time-resolved immunoflourometric assay for the detection of anti-hepatitis $\mathrm{C}$ virus total antibodies with improved specifity and sensitivity. J Medical Microbiol 57:1-7.

27- European Association for Study of Liver. (2014): EASL Clinical Practice Guidelines: (2014) management of hepatitis C virus infection.J Hepatol; 60: 392-420 